Jurnal Care Vol .5, No2,Tahun 2017

\title{
DUKUNGAN KELUARGA BERHUBUNGAN DENGAN KEPUASAN INTERAKSI SOSIAL PADA LANSIA
}

\author{
Sisilia Ndore ${ }^{1}$, Sulasmini ${ }^{2}$, Tanto Hariyanto ${ }^{3}$ \\ 1,2) Program Studi Ilmu Keperawatan Fakultas Ilmu Kesehatan Universitas Tribhuwana \\ Tunggadewi Malang \\ 3) Program Studi Keperawatan Poltekkes Kemenkes Malang \\ e-mail : Sela.ndore90@gmail.com
}

\begin{abstract}
The elderly has physically decreased includes the five sense abilities which affects their life activities and motions. These health status and physical opportunity degressions impact on lowering the social interaction for elderly. Here, the family existence and also its support strongly needed by the elderly. The purpose of this research is to perceive the correlation of family support and elderly satisfaction on the social interaction at Posyandu Lansia Permadi Kecamatan Lowokwaru Malang. This research is correlational analytic research with cross sectional approach. The population in this study as many as 211 people with a sample of 33 people taken by purposive sampling. The instrument was a questionnaire sheet with spearman rank data analysis. The results showed that as many as 25 people (78.5\%) most of the support of the family with good category and most of high category on social interaction satisfaction as many as 19 people (57.5\%). The data analysis result showed that between family support and social interaction satisfaction at Elderly at Posyandu Permia Permadi Kecamatan Lowokwaru Malang are correlated.
\end{abstract}

Keywords : elderly satisfaction on social interaction, family support

\begin{abstract}
ABSTRAK
Lansia telah mengalami penurunan kemampuan tubuh dan panca indera, berpengaruh pada aktivitas dan gerak dalam kehidupannya. Penurunan derajat kesehatan dan kesempatan fisik tersebut menyebabkan terjadinya penurunan interaksi sosial pada lansia. Adanya dukungan keluarga sangat dibutuhkan oleh lansia. Tujuan dalam penelitian ini adalah untuk mengetahui hubungan dukungan keluarga dengan kepuasan interaksi sosial pada lansia di Posyandu Lansia Permadi Kecamatan Lowokwaru Malang. Penelitian ini merupakan penelitian analitik korelasional dengan pendekatan cross sectional. Populasi dalam penelitian ini sebanyak 211 orang dengan sampel 33 orang yang diambil dengan purposive sampling. Instrumen yang digunakan adalah lembar kuesioner dengan analisa data spearman rank. Hasil penelitian menunjukan bahwa sebagian besar dukungan keluarga dengan kategori baik sebanyak 25 orang (78,5\%) ; dan sebagian besar kepuasan interaksi sosial dengan kategori tinggi yakni sebanyak 19 orang $(57,5 \%)$. Hasil analisa data didapatkan ada hubungan antara
\end{abstract}


dukungan keluarga dengan kepuasan interaksi sosial pada Lansia di Posyandu Lansia Permadi Kecamatan Lowokwaru Malang.

Kata kunci : Dukungan Keluarga, Kepuasan Interaksi Sosial Pada Lansia

\section{PENDAHULUAN}

Interaksi sosial memainkan peranan sangat penting bagi kehidupan lansia. Ini dikarenakan pada usia lanjut,para lansia mengalami penurunan kemampuan tubuh dan panca indera sehingga berpengaruh dalam aktivitas dan gerak lansia. Penurunan kemampuan membuat para lansia tidak sanggup lagi berpergian jauh, tidak terlalu peka pada suara yang pelan, pada tulisan yang tidak terlalu besar, bahkan pada kondisi tertentu sering lupa dan tidak dapat mengingat hal-hal yang baru saja di alaminya( pikun) (Suwignyo, 2010).

Menurunnya derajat kesehatan dan kesempatan fisik tersebut, mengakibatkan seorang lansia secara perlahan menarik diri dalam berhubungan dengan masyarakat sekitar. Sesuatu yang kemudian menyebabkan menurunnya interaksi sosial para lansia (Hardywininoto dan Setiabudi, 1999), yang pada gilirannya justru akan menurunkan kualitas hidup para lansia itu sendiri. Sedangkan kualitas hidup pada umumnya ditakar dengan tingkat kesehatan masyarakat Indonesia dan sangat berkaitan dengan meningkatnya Usia Harapan Hidup (UHH). Tahun 2004 UHH penduduk Indonesia adalah 66,2 tahun, kemudian meningkat menjadi 69,4 pada tahun 2006.

Kepuasan hidup pada usia lanjut akan muncul apabila kebutuhan dan keinginan individu pada waktu tertentu terpenuhi dan terpuaskan. Individu yang baik dalam penyesuaian diri, dalam arti bahwa individu dapat memuaskan kebutuhan dan keinginannya dengan cukup dan dalam batas kontrol yang baik akan jauh lebih bahagia daripada individu yang tidak dapat atau yang tidak mampu melakukan penyesuaian yang esensial (Hurlock, 1997).

Berdasarkan hasil studi pendahuluan yang dilakukan oleh peneliti dengan mewawancarai tiga orang lansia di Posyandu Permadi Lowokwaru Malang, didapatkan satu diantara lansia tersebut 
merasa anggota keluarganya tidak mengizinkan untuk mengikuti sosialisasi atau kegiatan warga yang diadakan di lingkungannya. Lansia tidak melakukan interaksi dengan orang lain dan juga interaksi sosial dengan anggota keluarga juga tidak baik. Sehubungan dengan berbagai kondisi para lansia tersebut, peneliti tertarik untuk meninjaunya lebih jauh lagi lewat penelitian yang berjudul hubungan dukungan keluarga dengan kepuasan interaksi sosial pada lansia di Posyandu Lansia Permadi Permadi Lowokwaru Malang.

\section{METODE PENELITIAN}

Desain penelitian yang digunakan dalalam penelitian ini adalah analitik korelasional, yakni menghubungkan antara variabel dukungan keluarga dengan kepuasan interaksi sosial lansia. Populasi dalam penelitian ini sebanyak 211 orang dan sampel penelitian sejumlah 33 orang diambil dengan menggunakan purposive sampling. Teknik pengumpulan data yang digunakan adalah lembar kuisioner -Variabel independen dalam penelitian ini adalah dukungan keluarga lansia dan varibel dependent adalah kepuasan interaksi sosial lansia. Analisis data yang di gunakan dalam penelitian ini adalah menggunakan korelasi spearman rank dengan derajat kemaknaan $\alpha<0,05$, artinya apabila $\mathrm{p}<0,05$ maka Ho di tolak yang berarti ada hubungan yang bermakna antara tipe kepribadian dengan tingkat kepuasan interaksi.

\section{HASIL}

Tabel 1. Distribusi Frekuensi Jenis Kelamin Keluarga Responden di Posyandu Permadi Lowokwaru Malang

\begin{tabular}{lll}
\hline Jenis Kelamin & Jumlah & $\%$ \\
\hline Laki-laki & 14 & 42.4 \\
Perempuan & 19 & 57.6 \\
\hline Total & 33 & 100 \\
\hline
\end{tabular}

Berdasarkan Tabel 1 dapat diketahui bahwa sebagian besar keluarga responden $(57,6 \%)$ berjenis kelamin perempuan sebanyak 19 orang.

Tabel 2. Distribusi Frekuensi Tingkat Pendidikan Keluarga Responden di Posyandu Permadi Lowokwaru Malang

\begin{tabular}{lcc}
\hline Pendidikan & Jumlah & $\%$ \\
\hline SD & 10 & 30.3 \\
SMP & 8 & 24.2 \\
SMA & 9 & 27.3 \\
Perguruan Tinggi & 6 & 18.2 \\
\hline Total & 33 & 100 \\
\hline
\end{tabular}

Berdasarkan Tabel 2 dapat diketahui bahwa hampir sebagian (30,3\%) dari keluarga responden mempunyai pendidikan SD yakni sebanyak 10 orang. 
Tabel 3. Distribusi Frekuensi Berdasarkan Dukungan Keluarga di Posyandu Permadi Lowokwaru Malang

\begin{tabular}{lcc}
\hline Dukungan Keluarga & Jumlah & $\%$ \\
\hline Kurang & 0 & 0 \\
Cukup & 8 & 24.2 \\
Baik & 25 & 75.8 \\
\hline Total & 33 & 100 \\
\hline
\end{tabular}

Berdasarkan Tabel 3 dapat dilihat bahwa sebagian besar $(75,8 \%)$ dukungan keluarga responden masuk kategori baik yakni sebanyak 25 orang.

Tabel 4. Distribusi Frekuensi Berdasarkan Kepuasan Interaksi Sosial Lansia di Posyandu Permadi Lowokwaru Malang

\begin{tabular}{lcc}
\hline Kepuasan & Jumlah & $\%$ \\
Interaksi Sosial & & \\
\hline Rendah & 0 & 0 \\
Cukup & 14 & 42.4 \\
Tinggi & 19 & 57.6 \\
\hline Total & 33 & 100 \\
\hline
\end{tabular}

Berdasarkan Tabel 4 dapat dilihat bahwa sebagian besar $(57,6 \%)$ kepuasan interaksi sosial lansia termasuk dalam kategori tinggi yakni 19 orang.

\section{PEMBAHASAN}

Sebagian besar $(75,8 \%)$ dukungan keluarga responden masuk kategori baik. Hal ini dapat disampaikan bahwa keluarga memberikan perhatian yang baik untuk lansia. Menurut Friedman (2003) dukungan keluarga merupakan suatu strategi intervensi preventif yang paling baik dalam membantu anggota keluarga.

Dukungan keluarga mengacu pada dukungan yang dipandang oleh anggota keluarga sebagai suatu yang dapat diakses untuk keluarga misalnya dukungan dapat atau tidaknya digunakan, namun berbeda dengan anggapan anggota keluarga yang memandang bahwa orang yang bersifat mendukung harus selalu siap dalam memberikan pertolongan dan bantuan jika diperlukan.

Menurut peneliti, dukungan keluarga dapat berupa dukungan keluarga internal, seperti dukungan dari suami istri atau dukungan dari saudara kandung atau dukungan sosial keluarga eksternal yang diberikan kepada lansia (kakek dan nenek pada anggota keluarga).

Dukungan keluarga yang baik dapat dipengaruhi oleh berbagai faktor.Salah satu faktor yang mempengaruhinya seperti jenis kelamin. Dari hasil penelitian, diketahui bahwa sebagian besar $(57,6 \%)$ dari keluarga responden berjenis kelamin perempuan sebanyak 19 orang dan hampir sebagian (42,2\%) dari keluarga responden berjenis kelamin laki-laki berjumlah 14 orang. 
Jurnal Care Vol .5, No2,Tahun 2017

Sebagian besar (57,6\%) kepuasan interaksi sosial lansia dalam kategori tinggi yakni sebanyak 19 orang. Dapat disampaikan bahwa berarti bahwa lansia merasakan adanya perasaan senang dan dapat melakukan interaksi sosial. Sesuai dengan Chaplin (1999) yang menyatakan bahwa kepuasan merupakan kondisi subyektif dari keadaan pribadi seseorang berhubungan dengan perasaan senang atau tidak senang sebagai akibat dari adanya dorongan atau kebutuhan yang ada pada dirinya dan dihubungkan dengan kenyataan yang di rasakan. Interaksi sosial yang baik pada diri lansia dapat memberikan dampak perasaan yang bahagia pula pada diri lansia, dan ini muncul sebagai akibat adanya tanggapan dari lingkungan sekitar akan keberadaannya. Sesuai dengan Maryati dan Suryawati (2003) menyatakan bahwa, "Interaksi sosial adalah kontak atau hubungan timbal balik atau interstimulasi dan respons antar individu, antar kelompok atau antar individu dan kelompok".

Tinggi rendahnya kepuasan interaksi sosial pada lansia dipengaruhi oleh beberapa faktor, salah satunya adalah faktor kesehatan. Jika lansia mempunyai permasalahan kesehatan (sakit), maka secara tidak langsung akan berdampak pada penurunan interaksi sosial pada diri lansia. Sesuai dengan Hidayat (2007) bahwa faktor-faktor yang dapat mempengaruhi mempengaruhi kepuasan interaksi sosial lansia yaitu kesehatan, daya tarik fisik, tingkat otonomi, kesempatan interaksi sosial di luar keluarga, jenis pekerjaan, status kerja, kondisi kehidupan, pemilikan harta benda, keseimbangan antara harapan dan pencapaian, penyesuaian emosional, sikap terhadap periode usia tertentu, realisme dari konsep diri dan realisme dari konsep peran Salah satu faktor yang diambil untuk penelitian ini adalah interaksi dengan lingkungan luar keluarga karena interaksi seseorang tidak hanya terbatas pada lingkungan keluarga saja, tetapi denagan adanya pola kehidupan yang memungkinkan seseorang untuk berinteraksi dengan orang-orang di lingkungan luar keluarga (tetangga) juga akan memperbesar kepuasan hidup seseorang.

\section{Hubungan Dukungan Keluarga} Dengan Kepuasan Interaksi Sosial Pada Lansia

Sebagian besar (75,8\%) dukungan keluarga responden masuk kategori baik 
sebanyak 25 orang. Ini berarti bahwa dengan dukungan keluarga yang baik untuk lansia, maka akan memberikan kebahagiaan tersendiri untuk lansia,lansia tidak merasa terbatasi serta dapat bergerak secara alami tanpa tekanan apapun.

Berdasarkan analisis data dengan mengunakan uji korelasi spearman rank dengan mengunakan bantuan SPSS versi 17 for Window, didapat $p$ value $=0,00<\alpha$ $(0,05)$ yang berarti $\mathrm{H}_{0}$ ditolak, artinya ada hubungan antara dukungan keluarga dengan kepuasan interaksi sosial pada lansia. Adanya hubungan dukungan keluarga dengan kepuasan interaksi sosial pada lansia dikarenakan adanya faktor saling keterikatan antara angggota keluarga yang lain. Keluarga yang mendukung lansia dalam melakukan aktifitas dan membicarakan setiap masalah yang ada, maka akan memberi dampak yang positif seperti memberi rasa kehangatan dan suasana damai dalam lingkungan keluarga.

Dukungan keluarga yang baik pada lansia menjadikan hubungan kepuasan interaksi pada lansia menjadi tinggi pada setiap anggota keluarganya. Sependapat dengan Hurlock (1997) bahwa kepuasan hidup pada usia lanjut akan timbul dan dialami apabila kebutuhan dan keinginan individu pada waktu tertentu terpenuhi dan terpuaskan. Individu yang baik dalam penyesuaian diri, dalam arti bahwa individu dapat memuaskan kebutuhan dan keinginannya dengan cukup dan dalam batas kontrol yang baik akan jauh lebih bahagia daripada individu yang tidak dapat atau yang tidak mampu melakukan penyesuaian yang esensial.

Dukungan dari keluarga merupakan unsur terpenting dalam membatu lansia menyelesaikan semua masalah yang dihadapinya. Apabila ada dukungan dari keluarg, maka rasa percaya diri akan bertambah dan motivasi untuk menghadapi masalah yang terjadi akan meningkat (Setiadi 2008).

Dukungan keluarga yang baik berawal dari pengetahuan yang baik, dan pengetahuan yang baik dimungkinkan dari pendidikan keluarga yang baik pula. Pendidikan seseorang memberikan pengaruh pada pola pikir terhadap diri dan lingkungan sekitarnya. Individu yang memiliki tingkat pendidikan yang tinggi akan memiliki pemikiran yang matang, dan didharapkan akan mampu 
memberikan dukungan yang baik pula untuk orang tuanya.

\section{KESIMPULAN}

1. Sebagian besar $(75,8 \%)$ dukungan keluarga responden masuk kategori baik sebanyak 25 orang.

2. Sebagian besar $(57,6 \%)$ lansia mempunyai kepuasan interaksi sosial yang tinggi yakni 19 orang

3. Ada hubungan antara dukungan keluarga dengan kepuasan interaksi sosial pada lansia di Posyandu Lansia Permadi RW 02 RT 02 Tlogo Soryo Malang

\section{REFERENSI}

Chaplin, J.P. (1999). Kamus Lengkap psikologi (Terjemahan dari Dr. Kartini Kartono), Jakarta : PT. Raja Grafindo Persada.

Friedman, M. M. (2003). Family nursing research theory and practice. 5tabun Ed. Stamford: appieton \& lange.

Hidayat, A. A. (2007). Metode Penelitian Keperawan Dan Teknik Analisa Data. Salemba Medika. Jakarta

Hurlock E.B.(1997). Psikologi Perkembangan Suatu Pendekatan Sepanjang Rentang Kehidupan edisi 5. Jakarta : Penerbit Erlangga.
Maryati,Suryawati.(2003). Interaksi sosial: defenisi, bentuk, syrat terjadinya interaksi. (http://jurnalsdm.blogspot.com/2009/05/int eraksi-sosial-definisi-bentukciri.html diakses 6 Maret 2014)

Setiadi. (2008). Konsep \& keperawatan keluarga. Yogyakarta : Graha Ilmu.

Suwignyo, Agus.(2010). Kurikulum dan Politike (Kebijakan) Pendidikan, (dalam Forum Mangunwijaya, Kurikulum yang Mencerdaskan Visi 2030 dan Pendidikan Alternatif). Jakarta: PT Kompas Media Nusantara. 